\title{
EHMTI-0282. Deep brain stimulation in chronic cluster headache: lead location, clinical response and neuronal signatures
}

\author{
S Miller ${ }^{1 *}$, F Rasul ${ }^{2}$, M Matharu ${ }^{1}$, A Pogosyan ${ }^{3}$, P Brown ${ }^{3}$, M Hariz $^{2}$, L Zrinzo $^{2}$ \\ From 4th European Headache and Migraine Trust International Congress: EHMTIC 2014 \\ Copenhagen, Denmark. 18-21 September 2014
}

\section{Background}

Chronic Cluster Headache $(\mathrm{CCH})$ is refractory to medical therapy in a small minority of patients. Neuroimaging implicateS the ipsilateral posterior hypothalamic region $(\mathrm{PH})$ in its pathogenesis. $\mathrm{PH}$ deep brain stimulation (PH-DBS) has shown promise in the management of refractory $\mathrm{CCH}$. Here we investigate the value of local field potentials (LFPs) in relation to the site of active DBS contact used for chronic stimulation.

\section{Methods}

Four patients with refractory $\mathrm{CCH}$ treated with $\mathrm{PH}-\mathrm{DBS}$ were investigated. The target on stereotactic T2-weighted images lay in the anteromedial quadrant between the red nucleus and mammillary bodies. LFPs were recorded from externalised wires prior to implantation of the impulse generator a week after lead implantation.

\section{Results}

All leads were within $1.0 \mathrm{~mm}$ of the intended target point. Mean(range) coordinates of the chronically active contact were $3.6(2.0-5.40) \mathrm{mm}$ lateral, $3.1(1.2-5.0) \mathrm{mm}$ posterior and $5.0(2.0-8.6) \mathrm{mm}$ inferior to the midcommissural point. Mean follow-up was 23(15-26) months. Headache load was defined as the [severity (on the visual analogue scale)] $\mathrm{x}$ [duration] $\mathrm{x}$ [frequency]) of cluster headache. Headache load reduced by $57,58,68$ and $100 \%$ in each patient. LFP peaks were noted in 3 out of 4 cases (at 8,11 and $15 \mathrm{~Hz}$ ). The contacts used for stimulation at last follow-up coincided with one or both of the contacts affording the highest amplitude peak in bipolar recordings.

\section{Conclusions}

Our results support previous data that PH-DBS may be useful in patients with medically refractory cluster headache. LFP activity may potentially be useful in guiding contact selection during programming and deserves further investigation.

No conflict of interest.

\section{Authors' details}

'Headache, UCL Institute of Neurology, London, UK. ${ }^{2}$ Functional Neurosurgery, UCL Institute of Neurology, London, UK. ${ }^{3}$ Nuffield Department of Clinical Neurosciences, University of Oxford, Oxford, UK.

Published: 18 September 2014

doi:10.1186/1129-2377-15-S1-E19

Cite this article as: Miller et al:: EHMTI-0282. Deep brain stimulation in chronic cluster headache: lead location, clinical response and neuronal signatures. The Journal of Headache and Pain 2014 15(Suppl 1):E19.

Submit your manuscript to a SpringerOpen ${ }^{\circ}$ journal and benefit from:

- Convenient online submission

- Rigorous peer review

- Immediate publication on acceptance

- Open access: articles freely available online

- High visibility within the field

- Retaining the copyright to your article

Submit your next manuscript at $\gg$ springeropen.com

'Headache, UCL Institute of Neurology, London, UK

Full list of author information is available at the end of the article

(c) 2014 Miller et al; licensee Springer. This is an Open Access article distributed under the terms of the Creative Commons Attribution License (http://creativecommons.org/licenses/by/2.0), which permits unrestricted use, distribution, and reproduction in any medium, provided the original work is properly cited. 